\title{
Epidermal Growth Factor Enhances Renal Tubule Cell Regeneration and Repair and Accelerates the Recovery of Renal Function in Postischemic Acute Renal Failure
}

\author{
H. David Humes, Deborah A. Cieslinski, Terezila M. Coimbra, Joseph M. Messana, and Carlos Galvao \\ Departments of Internal Medicine, Veterans Administration Medical Center, and University of Michigan, Ann Arbor, Michigan 48105
}

\begin{abstract}
To determine the timing and location of renal cell regeneration after ischemic injury to the kidney and to assess whether exogenous epidermal growth factor (EGF) enhances this regenerative repair process to accelerate recovery of renal function, experiments were undertaken in rats undergoing $30 \mathrm{~min}$ of bilateral renal artery clamp ischemia followed by reperfusion for varying time intervals. Renal cell regeneration, as reflected by incorporation of radiolabeled thymidine within the kidney, began between 24 to $48 \mathrm{~h}$ and reached a peak at $72 \mathrm{~h}$ after renal ischemia. As demonstrated by histoautoradiography, renal thymidine incorporation was essentially confined to tubule cells. Morphometric analysis of histoautoradiograph sections of renal tissue demonstrated that the majority of labeled cells were found in renal cortex, but some labeled cells were also located in the inner stripe of the outer medulla, suggesting that injury to medullary thick ascending limbs also occurs in this ischemic model. Exogenous EGF administration produced increases in renal thymidine incorporation compared with nontreated animals at 24,48 , and $72 \mathrm{~h}$ after ischemic injury. This accelerated DNA replicative process was associated with significantly lower peak blood urea nitrogen (BUN) and serum creatinine levels, averaging $63 \pm 20$ and $3.1 \pm 0.4 \mathrm{mg} / \mathrm{dl}$ in EGFtreated ischemic rats compared with $149 \pm 20$ and $5.1 \pm 0.1$ $\mathrm{mg} / \mathrm{dl}$, respectively, in nontreated ischemic rats, and was also associated with a return to near normal BUN and serum creatinine levels in EGF-treated animals $\sim 4 \mathrm{~d}$ earlier than that observed in nontreated animals. This report is the first demonstration that EGF accelerates the repair process of a visceral organ after an injurious insult.
\end{abstract}

\section{Introduction}

Fixed structural ischemic acute renal failure is due to renal tubule epithelial cell injury (1) but it is a reversible disease process, with renal excretory function returning to normal within several days to weeks after injury (2). This reversibility depends on the ability of renal tubule cells to regenerate and reline the damaged areas of epithelium along the nephron. Since epidermal growth factor (EGF) ${ }^{1}$ is one of the most po-

This work was presented in part at the Annual Meetings of the American Society of Nephrology, 11 December 1988, San Antonio, TX and of the American Society of Clinical Investigation, 28 April 1989, Washington, DC.

Address reprint requests to Dr. H. D. Humes, Chief, Medical Service (111), Veterans Administration Medical Center, 2215 Fuller Road, Ann Arbor, MI 48105.

Received for publication 27 January 1989 and in revised form 31 May 1989.

1. Abbreviations used in this paper: BUN, blood urea nitrogen; EGF, epidermal growth factor; MTAL, medullary thick ascending limb; TGF-alpha, transforming growth factor-alpha.

The Journal of Clinical Investigation, Inc.

Volume 84, December 1989, 1757-1761 tent mitogens of renal epithelial cells $(3,4)$, exogenous administration of EGF during the recovery phase of ischemic acute renal failure may accelerate renal epithelial cell regeneration and speed the time for recovery of renal excretory function. These experiments were, therefore, carried out to assess the effect of exogenous administration of EGF to enhance this replicative and recovery process.

\section{Methods}

Sprague Dawley rats (250-325 g) were anesthetized with a short-acting barbiturate, the abdominal cavity was exposed, and both left and right renal arteries were identified and clamped for $30 \mathrm{~min}$. The clamps were released and perfusion to the kidneys reestablished. At time intervals of 24,48 , and $72 \mathrm{~h}$ after ischemia and reperfusion, $\left[{ }^{3} \mathrm{H}\right]$ thymidine incorporation into kidneys, as well as blood urea nitrogen (BUN) and serum creatinine levels, were determined with methods detailed previously for this laboratory (5). In brief, $1 \mathrm{~h}$ before being killed, rats were given intraperitoneal injections of $200 \mu \mathrm{Ci}$ of [methyl- ${ }^{3} \mathrm{H}$ ] thymidine diluted in $0.25 \mathrm{ml}$ of sterile water. After the rats were killed by decapitation and exsanguination, the kidneys were quickly removed and cut longitudinally. Portions $(100 \mathrm{mg}$ ) of the kidney were placed in cryogenic tubes and snap-frozen in liquid nitrogen. Samples were stored at -20 to $-70^{\circ} \mathrm{C}$ for a maximum of $6 \mathrm{~d}$ before processing. Tissue samples were homogenized in ice-cold distilled water using a tissumizer (Tekmar Co., Cincinnati, OH). DNA was purified from $1.0 \mathrm{ml}$ of homogenate. To obtain a complete time course, some animals were allowed to recover for $7 \mathrm{~d}$ after renal ischemia and blood samples were then obtained daily for BUN or serum creatinine measurements.

Radioactivity was measured on $0.5 \mathrm{ml}$ of sample in $20 \mathrm{ml}$ of Safety-Solve (Research Products International Corp., Mt. Prospect, IL) in a scintillation counter (model 9000; Beckman Instruments, Inc., Fullerton, CA). Counting efficiency was estimated by an internal standard. Serum samples were counted to assure consistent intraperitoneal absorption of the $\left[{ }^{3} \mathrm{H}\right]$ thymidine. Samples of the DNA extract were counted and corrected for sample DNA content.

To localize and identify the cells incorporating the radiolabeled thymidine within the kidney, histoautoradiography of kidney samples was also accomplished using methods previously published from this laboratory (5). Kidneys were perfused in vivo with $2 \%$ glutaraldehyde in $0.1 \mathrm{M}$ sodium cacodylate buffer ( $\mathrm{pH} 7.2$ ). Tissue sections from kidneys were placed in $4 \%$ formaldehyde, $1 \%$ glutaraldehyde, $100 \mathrm{mM}$ phosphate buffer (7.2). Specimens were dehydrated and embedded in methacrylate. Tissue sections $(4 \mu \mathrm{m})$ were dipped in NBT-2 nuclear emulsion (Eastman Kodak Co., Rochester, NY) and stored in the dark at $4^{\circ} \mathrm{C}$ for $21 \mathrm{~d}$. The sections were developed and counterstained with Lee's methylene blue-basic fuchsin. For quantitative evaluation, a computerized operator-interactive system was used as described previously (5). Sections were examined at 176 magnification, and 10-15 fields were counted in the cortex and outer and inner stripes of the outer medulla in each section for an individual animal. The cell type of the labeled cells was identified as either tubular or interstitial.

For the experiments that used EGF, rats were administered EGF $(20 \mu \mathrm{g})$ subcutaneously $1-1.5 \mathrm{~h}$ after surgery. This dose of EGF is substantially lower than those employed in previously reported studies that administered EGF systemically $(6,7)$. At varying time points after reperfusion, measurements of $\left[{ }^{3} \mathrm{H}\right]$ thymidine incorporation into the 
kidneys and BUN, and serum creatinine levels were determined. Some animals receiving EGF were allowed to recover for up to $7 \mathrm{~d}$ with serial determinations of BUN and serum creatinine.

All reagents used were of the highest grade commercially available. All organic reagents were obtained from Sigma Chemical Co. (St. Louis, MO) unless otherwise indicated. [methyl- ${ }^{3} \mathrm{H}$ ] Thymidine was obtained from New England Nuclear (Boston, MA). EGF was obtained from Amgen Biologicals (Thousand Oaks, CA).

The $t$ test was used to determine statistical significance.

\section{Results}

The experimental design of this study produced a model of reversible ischemic acute renal failure, as demonstrated in Fig. 1. Renal excretory function declined quickly after $30 \mathrm{~min}$ of bilateral renal artery clamping as reflected by BUN levels rising in the first $24 \mathrm{~h}$ of reperfusion from an average ( $\pm \mathrm{SE}$ ) control level of $21 \pm 2$ to a mean of $126 \pm 9 \mathrm{mg} / \mathrm{dl}(n=12)$. BUN levels peaked to levels of $158 \pm 21(n=13)$ at $48 \mathrm{~h}$ after ischemic insult and progressively improved thereafter, returning to near normal levels by day $7(168 \mathrm{~h})$.

As an indication of an increase in cell regeneration, $\left[{ }^{3} \mathrm{H}\right]-$ thymidine incorporation into DNA of the kidney began to rise between 24 to $48 \mathrm{~h}$ after renal ischemia, demonstrating at least a 24-h delay compared with the rise in BUN levels. Peak $\left[{ }^{3} \mathrm{H}\right]-$ thymidine incorporation, averaging $255 \pm 78 \times 10^{3} \mathrm{dpm} / \mathrm{mg}$ DNA, occurred at $72 \mathrm{~h}$ and fell precipitously thereafter (Fig. 2).

Histoautoradiographic studies were performed to determine the location of the cells labeled with $\left[{ }^{3} \mathrm{H}\right]$ thymidine. Kidney sections from rats at $48 \mathrm{~h}$ after renal ischemia were used for histoautoradiographic analysis. Fig. 3 is representative of $\left[{ }^{3} \mathrm{H}\right]$ thymidine labeling in renal cortex from these rats. Labeling was confined to the nuclei. On average, $97.8 \%$ of the labeled cells were tubule cells (absolute number $=3,350$ cells) and $2.2 \%$ of the labeled cells were interstitial cells (absolute number $=73$ cells) in 90 fields evaluated. In control rats undergoing sham renal ischemia, $98.7 \%$ of labeled cells were tubule (absolute numbers $=230$ ) and $1.3 \%$ were interstitial (absolute number $=3$ ) in 90 examined fields. The distribution of labeled tubule cells in postischemic kidneys at $48 \mathrm{~h}$ (Table I) demonstrated that 52,33 , and $15 \%$ of all labeled tubule cells were located in cortex and outer and inner stripes of the outer medulla, respectively.

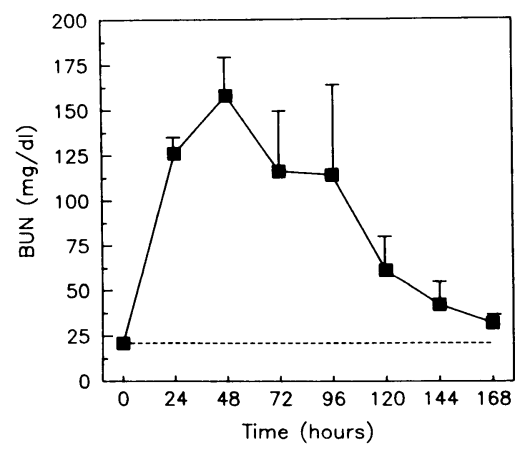

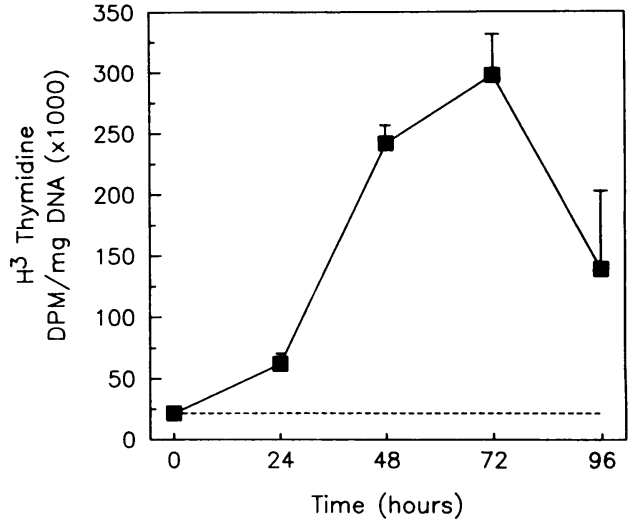

Figure 2. Effect of ischemic injury on renal thymidine incorporation. Time course of $\left[{ }^{3} \mathrm{H}\right]$ thymidine incorporation into kidneys of rats undergoing $30 \mathrm{~min}$ of bilateral renal artery clamping and reperfusion of the kidney for varying time periods. Values (mean $\pm \mathrm{SE}$ ) at time points 48,72 , and $96 \mathrm{~h}$ were statistically different from control levels $(P<0.01$ or better, $n=3-7)$. $m$, ischemia; ----, control.

A single dose of exogenously administered EGF at $1-1.5 \mathrm{~h}$ after reperfusion significantly increased renal thymidine incorporation compared with control nontreated ischemia values measured at 24,48 , and $72 \mathrm{~h}$ of reperfusion after $30 \mathrm{~min}$ of bilateral renal artery clamping, as depicted in Fig. 4. Thus, EGF both accelerated and enhanced renal thymidine incorporation at all time periods through the peak replicative and repair response of renal tubule cells compared with values of the nontreated ischemia group. EGF treatment of rats undergoing sham ischemia did not show any increase in $\left[{ }^{3} \mathrm{H}\right]-$ thymidine incorporation in kidneys. At $24 \mathrm{~h}$ and after a single dose of EGF in rats undergoing sham ischemia, renal $\left[{ }^{3} \mathrm{H}\right]-$ thymidine incorporation averaged $14 \pm 5 \times 10^{3} \mathrm{dpm} / \mathrm{mg}$ DNA, compared with a value of $11 \pm 2 \times 10^{3} \mathrm{dpm} / \mathrm{mg}$ DNA in nonEGF-treated sham animals $(P=\mathrm{NS}, n=3)$.

Histoautoradiographic studies were performed to determine the location of the cells labeled with $\left[{ }^{3} \mathrm{H}\right]$ thymidine in kidney sections from rats treated with EGF at $24 \mathrm{~h}$. Labeling was once again almost exclusively in tubule cells with, on average, $98.1 \%$ of labeled cells identified as tubule (absolute number $=3,183$ ) and $1.9 \%$ labeled cells (absolute number $=61$ ) identified as interstitial cells. The distribution of labeled tubule cells in postischemic kidneys at $24 \mathrm{~h}$ after EGF administrations demonstrated that 27,68 , and $5 \%$ of labeled cells were found in cortex and outer and inner stripes of the outer medulla, respectively. This distribution demonstrates a modest shift towards earlier repair in the outer stripe after EGF treatment compared with untreated ischemic kidneys.

Associated with this EGF-induced enhancement of tubule cell thymidine incorporation, the time course of renal excretory failure, as measured by both BUN and serum creatinine levels after ischemic injury, was dramatically altered by EGF treatment as demonstrated in Figs. 5 and 6. A group of animals were treated with a single dose of EGF within 1-1.5 h of reperfusion after $30 \mathrm{~min}$ of bilateral renal ischemia and followed for 3-7 d. The BUN and creatinine levels of EGF-treated animals, when compared with non-EGF-treated ischemia animals, were significantly lower during the entire 7-d period of acute renal failure, demonstrating an EGF-mediated enhancement in renal function recovery after ischemia. 

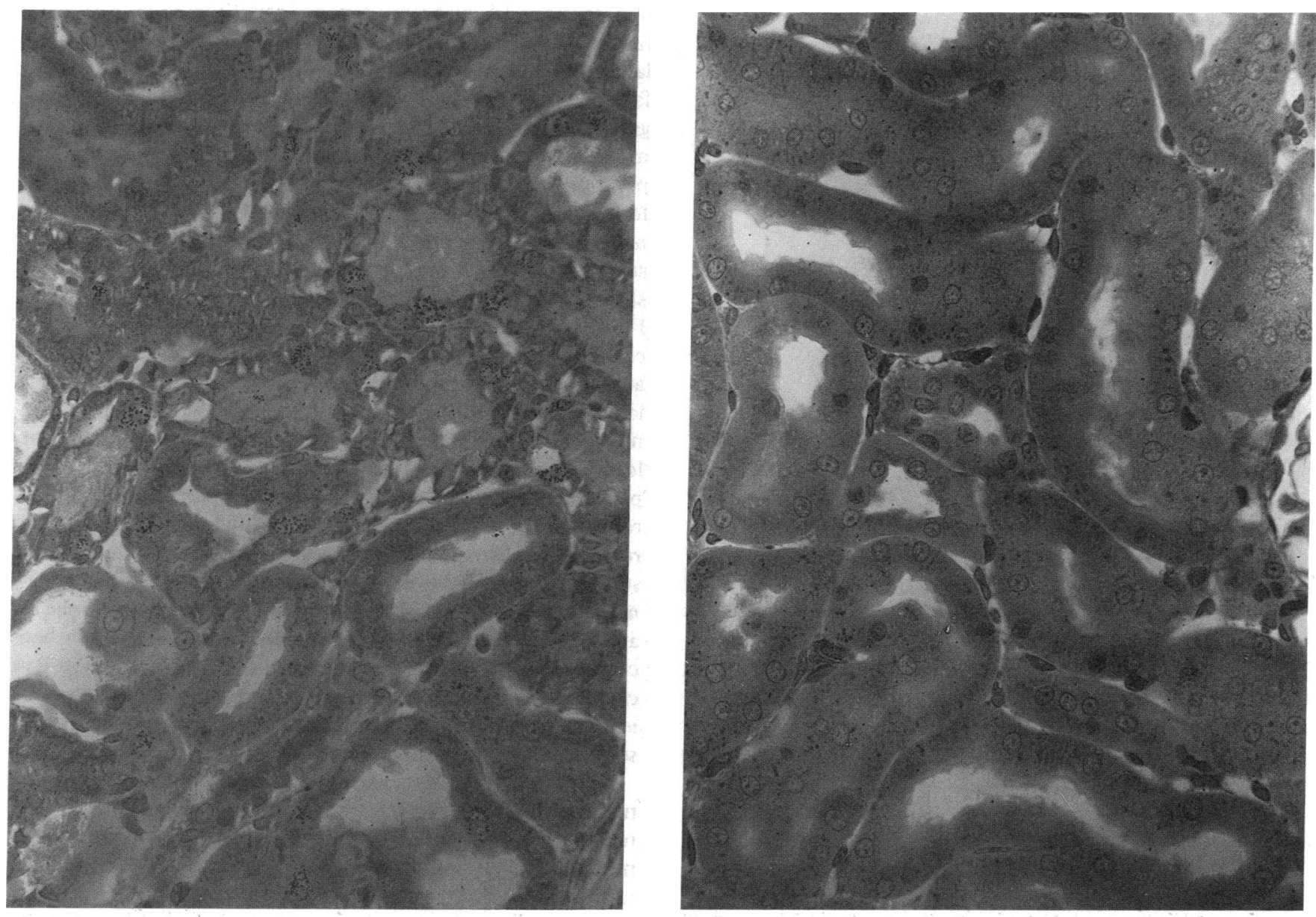

Figure 3. Histoautoradiography of the renal cortex of kidneys from rats undergoing $30 \mathrm{~min}$ of bilateral renal ischemia and $48 \mathrm{~h}$ of reperfusion (left) or sham ischemia (right). $\left[{ }^{3} \mathrm{H}\right]$ Thymidine label is observed as black silver grains above tubule cell nuclei.

\section{Discussion}

The syndrome of ischemic acute renal failure, as it occurs clinically and in animals, results from a complex interplay among cellular, nephronal, and hemodynamic processes. It is now widely recognized that loss of renal tubular epithelial cell viability results in loss of continuity of the tubular epithelium along the nephron and formation of cellular debris from injured tubule cells $(1,8)$. These processes promote derangements in nephronal function and integrity by producing intratubular obstruction and backleak of glomerular filtrate and results in renal excretory failure $(8,9)$. Consequently, the reversibility of ischemic acute renal failure depends on renal

Table I. Location of $\left[{ }^{3} \mathrm{H}\right]$ Thymidine-labeled Tubule Cells in Kidney 48 h after Ischemia

\begin{tabular}{cccc}
\hline & & \multicolumn{2}{c}{ Outer medulla } \\
\cline { 3 - 4 } & Cortex & Outer stripe & Inner stripe \\
\hline Cells/field & $59.6 \pm 3.8$ & $37.6 \pm 5.1$ & $18.0 \pm 3.3$ \\
\hline
\end{tabular}

Data expressed as mean \pm SE for $n=30-45$ fields. epithelial cell regeneration to reconstruct normal nephronal architecture, so that normal urine formation can be reestablished.

The results of the present experiments demonstrate that renal tubule cell repair and regeneration, as reflected by incorporation of radiolabeled thymidine within the kidney, begins between 24 to $48 \mathrm{~h}$ after a period of bilateral renal ischemia of sufficient duration to produce a model of reversible renal excretory failure. As demonstrated by histoautoradiography, this

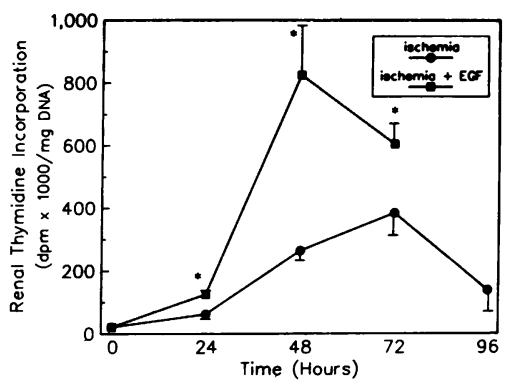

Figure 4. Time course for renal thymidine incorporation in rats undergoing 30 min of bilateral renal ischemia and varying periods of reperfusion. The group of animals receiving a single dose of EGF (20 $\mu \mathrm{g}$ ) within $1-1.5 \mathrm{~h}$ of reperfusion had significantly higher values $\left({ }^{*} P\right.$

$<0.05$ or better, $n=4-8$ ) compared with nontreated ischemia animals for all measured time points after reperfusion. 


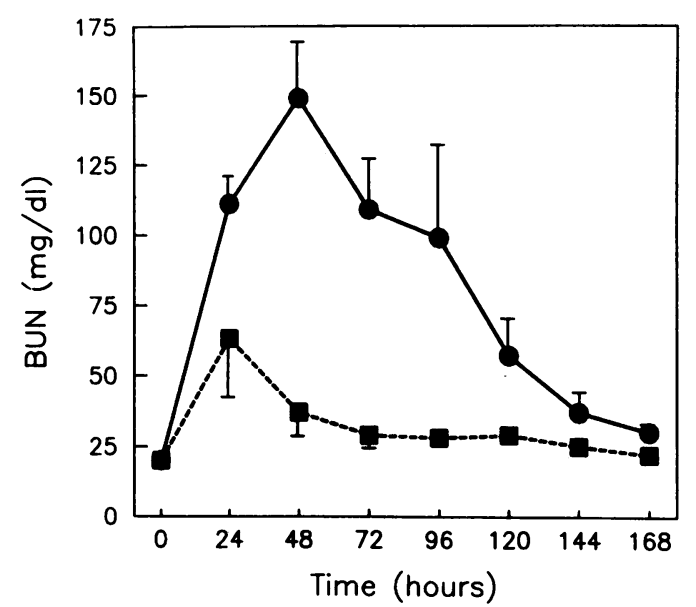

Figure 5. Time course for BUN values in rats undergoing $30 \mathrm{~min}$ of bilateral renal ischemia and varying periods of reperfusion. The group of animals receiving a single dose of EGF $(20 \mu \mathrm{g})$ within 1-1.5 $\mathrm{h}$ of reperfusion had BUN levels significantly lower at all time points than those in animals with renal ischemia not treated with EGF $(P$ $<0.02$ or better for all time points except $168 \mathrm{~h}$, where $P<0.05, n$ = 5-16). $\bullet$, ischemia; $₫$, ischemia + EGF.

renal thymidine incorporation was essentially confined to tubule cells.

Few studies have examined the timing of or mechanism responsible for renal tubule cell regeneration after acute tubular necrosis. One of the initial reports carefully evaluated the time course of renal tubule epithelial cell regeneration after mercuric chloride induced toxic acute renal failure in rats (10). This toxic process resulted in necrosis of proximal tubule cells during the initial $24 \mathrm{~h}$ after mercuric chloride administration. Epithelial cell regeneration and repair, as measured by radiolabeled thymidine incorporation, began to rise between 24 and $48 \mathrm{~h}$ and peaked at $72 \mathrm{~h}$ after toxin exposure. This regenerative process resulted in complete relining of the nephron by 4-5 d after mercuric chloride administration. This time course of tubule cell regeneration and repair was very similar to that observed during the repair phase after renal ischemia in this study.

Ischemic acute renal failure is also characterized histologically by injury and necrosis limited to only selected segments of the nephron. Most observations have indicated that proximal tubule damage, primarily in the pars recta $\left(S_{3}\right.$ rather than the $S_{1}$ and $S_{2}$ segments), predominates in animal models of ischemic acute renal failure $(8,11)$. More recent data have also suggested an important role for injury to medullary thick ascending limbs (MTAL) due to the precarious oxygenation of the renal medulla (12). This thesis was developed from observations of the susceptibility of MTAL to hypoxic injury in

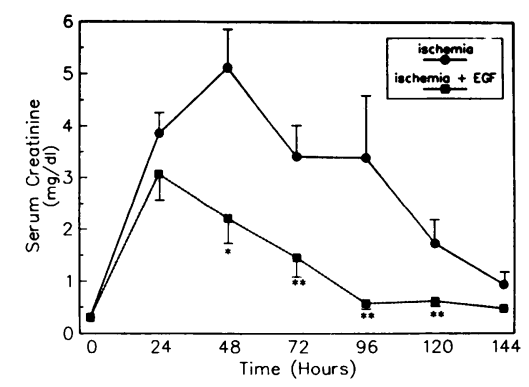

Figure 6. Time course for serum creatinine values for animals with ischemic renal injury. The animals treated with EGF had significantly lower $(* P<0.05$, ** $P<0.01, n=5-17$ ) values compared with untreated rats with ischemic renal injury. isolated perfused rat kidneys (13) and to both hemorrhagic hypotension (14) and simultaneous renal toxic and hypoperfusion stresses in whole animals (15). The occurrence and relationship of this segmental MTAL lesion to renal excretory failure, however, has been inconsistent and has, therefore, not gained widespread acceptance. In this regard, these experiments were undertaken to use radiolabeled thymidine incorporation as a more sensitive test than morphological criteria for the assessment of renal tubule cell injury $(5,16)$. Morphometric analysis of historadioautographic sections of renal tissue at $48 \mathrm{~h}$ after a 30 -min period of complete ischemia demonstrated that $>98 \%$ of the labeled cells were renal tubule cells. Furthermore, the majority of labeled cells were found in renal cortex, but substantial numbers were also located in the outer and inner stripes of the outer medulla. In fact, $15 \%$ of all labeled tubule cells were found in the inner stripe of the outer medulla. Because the $S_{3}$ segment of the proximal tubule is not located in the inner stripe (17), these cells could not be of proximal tubule origin. MTAL, however, predominate in this region of the kidney and the finding of labeled cells in this region is consistent with injury to this segment. In this regard, studies of the effects of anoxia on various renal tubular segments in primary explant culture have also revealed that the $\mathrm{S}_{3}$ and MTAL cells are most susceptible to anoxic injury when compared with cells from other nephron segments (18). Because regenerating cells do not possess morphologic characteristics of fully differentiated mature cells, clear identification of segmental origin of these cells was not possible.

This process of regeneration and repair by. surviving renal tubule cells most likely depends on the local production or release of growth-promoting substances. EGF may be instrumental in this renal regeneration process after acute tubular necrosis for several reasons. Proximal tubule cells (4), as well as cells from more distal segments of the nephron (19) and other nonepithelial renal cells (20), possess EGF receptors. EGF is a mitogen to proximal tubule cells in primary culture (4). EGF and transforming growth factor-alpha (TGF-alpha), which activates cells via the EGF receptor (21), are the most effective growth-promoting substances identified so far for renal proximal tubule cells (3). Substantially higher levels of EGF are found in urine compared with those found in blood, suggesting that the kidney may produce $\operatorname{EGF}(22,23)$. In fact, recent evidence has demonstrated that the kidney is a major site of synthesis for the precursor of EGF, prepro EGF. Prepro EGF mRNA levels have been localized to cells in the thick ascending limb of Henle and distal convoluted tubule $(24,25)$ and attain levels orders of magnitude higher in these nephron segments when compared with levels in other tissues. The presence of the EGF precursor in these distal nephron segments may suggest an autocrine pathway for EGF release to promote tubule cell replication after ischemic injury. A paracrine pathway for EGF or TGF-alpha release may also be initiated after renal ischemia to promote proximal tubule cell regeneration. Platelets have been demonstrated to be a rich source of EGF (26), as well as its functional homologue TGF-alpha (27). Platelet activation after ischemic injury to the kidney may release both EGF and TGF-alpha locally to promote proximal tubule cell replication.

The data presented in these current studies demonstrate that exogenously administered EGF can play an important role in the repair and recovery of renal injury after a significant ischemic event. Exogenous EGF produced an accelerated renal tubule epithelial cell regenerative and repair response 
compared with normal circumstances. This enhanced replicative and repair process led to more rapid relining of the injured renal tubular epithelium and a shortened time to recover renal excretory function. This improvement in renal excretory function with exogenous EGF administration after renal ischemia has also been recently reported in preliminary form from another laboratory (28).

EGF has also been demonstrated to be important in repair processes in other tissues. EGF found in saliva has been suggested to accelerate the repair of cutaneous wounds in rodents as they lick the area of injury (29). Topical administration of EGF enhanced the repair of skin injuries (30) and corneal abrasions $(31,32)$. TGF-alpha also has been shown to accelerate regeneration of the epidermis after partial thickness burns or split-thickness incisions in vivo (33). This report is the first demonstration that EGF may also accelerate the repair process of a visceral organ after an injurious insult.

\section{Acknowledgments}

The excellent technical assistance of Keith Gulyas, Ralph Reiss, Kay Brabec, and Revius Williams, and the expert secretarial support of Cecile Bagrow and Sandra Mariott is appreciated. The expert advice of Dr. Theodore Beals for the morphometric analysis is also appreciated.

These studies were supported by the VA Research Service, and by grants from the National Institutes of Health (R01 DK-30819 and P01 DK-39155).

\section{References}

1. Humes, H. D., and J. M. Weinberg. 1983. Alterations in renal tubular cell metabolism in acute renal failure. Miner. Electrolyte Metab. 9:290-305.

2. Swann, R. C., and J. P. Merrill. 1953. The clinical course of acute renal failure. Medicine (Baltimore). 32:215-292.

3. Humes, H. D., D. A. Cieslinski, T. Coimbra, and L. Johnson. 1989. Mitogenic response of rabbit renal proximal tubule cells to various growth factors. Clin. Res. 37:492A. (Abstr.)

4. Norman, J., B. Badie-Dezfooly, E. P. Nord, I. Kurtz, J. Schlosser, A. Chaudhari, and L. G. Fine. 1987. EGF-induced mitogenesis in proximal tubular cells: potentiation by angiotensin II. Am. J. Physiol. 253:F299-F309.

5. Jackson, N. M., C. Hsu, G. E. Visscher, M. L. Venkatachalam, and $H$. D. Humes. 1987. Alterations in renal structure and function in a rat model of cyclosporine nephrotoxicity. J. Pharmacol. Exp. Ther. 242:749-756.

6. Tashjian, A. H., Jr., E. F. Voelkel, W. Lloyd, R. Derynck, M. E. Winkler, and L. Levine. 1986. Actions of growth factors on plasma calcium: epidermal growth factor and human transforming growth factor-alpha cause elevation of plasma calcium in mice. J. Clin. Invest. 78:1405-1409.

7. Osamu, I., N. Hayashi, K. Masamoto, S. Kasuga, T. Fuwa, and S. Nakagawa. 1987. Long-latency growth-promoting activity of EGF when administered to mice at the neonatal stage. Am. J. Physiol. 253:E251-E254.

8. Donohoe, J. F., M. A. Venkatachalam, D. B. Bernard, and N. G. Levinsky. 1978. Tubular leakage and obstruction in acute ischemic renal failure. Kidney Int. 13:208-222.

9. Moran, S. M., and D. M. Bryan. 1985. Pathophysiology of protracted acute renal failure in man. J. Clin. Invest. 76:1440-1448.

10. Cuppage, F. E., M. Chiga, and A. Tate. 1972. Cell cycle studies in the regenerating rat nephron following injury with mercuric chloride. Lab. Invest. 26:122-126.

11. Venkatachalam, M. A., D. B. Bernard, J. F. Donohoe, and N. G. Levinsky. 1978. Ischemic damage and repair in the rat proximal tubule. Differences among the $\mathrm{S}_{1}, \mathrm{~S}_{2}$ and $\mathrm{S}_{3}$ segments. Kidney Int. 14:31-49.

12. Brezis, M., S. Rosen, P. Silva, and F. H. Epstein. 1984. Renal ischemia: a new perspective. Kidney Int. 26:375-383.
13. Brezis, M., S. Rosen, P. Silva, and F. H. Epstein. 1984. Selective vulnerability of the thick ascending limb to anoxia in the isolated perfused kidney. J. Clin. Invest. 73:182-189.

14. Kreisberg, J. I., R. E. Bulger, B. F. Trump, and R. B. Nagle. 1976. Effects of transient hypotension on the structure and function of the rat kidney. Virchows Arch. B. Cell Pathol. 22:121-133.

15. Heyman, S. N., M. Brezis, C. A. Reubinoff, Z. Greenfeld, C. Lechene, F. H. Epstein, and S. Rosen. 1988. Acute renal failure with selective medullary injury in the rat. J. Clin. Invest. 82:401-412.

16. Laurent, G., P. Maldague, M. Carlier, and P. M. Tulkens. 1983. Increased renal DNA synthesis in vivo after administration of low doses of gentamicin to rats. Antimicrob. Agents Chemother. 24:586593.

17. Bulger, R. E., and S. C. Herbert. 1988. Structural-functional relationships in the kidney. In Diseases of the Kidney. R. W. Schrier and C. W. Gottschalk, editors. Little, Brown and Co., Boston. 3-63.

18. Wilson, P. D., and R. W. Schrier. 1986. Nephron segment and calcium as determinants of anoxic cell death in renal cultures. Kidney Int. 29:1172-1179.

19. Breyer, M. D., H. R. Jacobson, and J. A. Breyer. 1988. Epidermal growth factor inhibits the hydroosmotic effect of vasopressin in the isolated perfused rabbit cortical collecting tubule. J. Clin. Invest. 82:1313-1320.

20. Harris, R. C., R. L. Hoover, H. R. Jacobson, and K. F. Badr. 1988. Evidence for glomerular actions of epidermal growth factors in the rat. J. Clin. Invest. 82:1028-1039.

21. Derynck R. 1988. Transforming growth factor alpha. Cell. 54:593-595.

22. Gregory, H. 1975. Isolation and structure of urogastorone and its relationship to epidermal growth factor. Nature (Lond.). 257:325327.

23. Olsen, P. S., E. Nexo, S. S. Poulsen, H. F. Hansen, and P. Kierkegaard. 1984. Renal origin of rat urinary epidermal growth factor. Regul. Pept. 10:37-43.

24. Rall, L. B., J. Scott, and G. I. Bell. 1985. Mouse prepro-epidermal growth factor synthesis by the kidney and other tissues. Nature (Lond.). 313:228-231.

25. Bell, G. I., N. M. Fong, M. M. Stempien, M. A. Wormsted, D. Caput, L. Ku, M. S. Urdea, L. B. Ral, and R. Sanchez-Pescador. 1986. Human epidermal growth factor precursor: cDNA sequence, expression in vitro and gene organization. Nucleic Acids Res. 14:8427-8446.

26. Oka, T., and D. N. Orth. 1983. Human plasma epidermal growth factor/B-urogastrone is associated with blood platelets. J. Clin. Invest. 72:249-259.

27. Assoian, R. K., G. R. Grotendorst, D. M. Miller, and M. B. Sporn. 1984. Cellular transformation by coordinated action of three peptide growth factors from human platelets. Nature (Lond.). 309:804-806.

28. Tsau, Y. K., J. J. Norman, and L. G. Fine. 1989. Epidermal growth factor enhances renal regeneration and accelerates recovery from ischemic acute renal failure. Kidney Int. 38:421. (Abstr.)

29. Niall, M., G. G. Ryan, and B. J. O'Brien. 1982. The effect of epidermal growth factor on wound healing in mice. J. Surg. Res. 33:164-169.

30. Brown, G. L., L. Curtsinger, J. R. Brightwell, D. M. Ackerman, G. L. Tobin, H. C. Polk, C. George-Nasciemento, Jr., P. Valenzuela, and G. S. Schultz. 1986. Enhancement of epidermal regeneration by biosynthetic epidermal growth factor. J. Exp. Med. 163:1319-1324.

31. Brightwell, J. R., S. L. Riddle, R. A. Eiferman, P. Valenzuela, P. J. Barr, J. P. Merryweather, and G. S. Schultz. 1985. Biosynthetic human EGF accelerates healing of Neodecadron-treated primate corneas. Invest. Ophthalmol. \& Visual Sci. 26:105-110.

32. Woost, P. G., J. Brightwell, R. A. Eiferman, and G. Schultz. 1985. Effect of growth factors with dexamethasone on healing of rabbit corneal stromal incisions. Exp. Eye Res. 40:47-60.

33. Schultz, G. S., M. White, R. Mitchell, G. Brown, J. Lynch, D. R. Twardzik, and G. J. Todaro. 1987. Epithelial wound healing enhanced by transforming growth factor-alpha and vaccinia growth factor. Science (Wash. DC). 235:350-352. 